Original Article

\title{
FORMULATION AND EVALUATION OF HERBAL TABLETS CONTAINING NYCTANTHES ARBOR- TRISTS LEAVES
}

\author{
PRASHANT CHAVAN ${ }^{*}$, MALLINATH KALSHETTI ${ }^{1}$, NIKHIL NAVINDGIKAR ${ }^{2}$
}

1Department of Pharmaceutical Quality Assurance, D. S. T. S. Mandal's College of Pharmacy, Solapur 413004, Maharashtra, India, ${ }^{2}$ Department of Pharmaceutics, D. S. T. S. Mandal's College of Pharmacy, Solapur 413004, Maharashtra, India

Email: chavanprashant299@gmail.com

Received: 20 Jan 2020, Revised and Accepted: 19 Mar 2020

\section{ABSTRACT}

Objective: To formulate arthritic pain relieving tablets and evaluation of tablets.

Methods: The preparation of dry powder of Nyctanthes arbor-tristis leaves, 1\% Acacia solution, 1\%HPMC-10 solution, 1\% Sodium alginate solution. The wet granulation method was used for the formulation of herbal tablets.

Results: Based on the pre-formulation study, the flow property of granules was good. The physical parameters of compressed tablets color were Greenish white for F1 and F3 batch, Dark greenish-white color for F2batch. The weight variation test, hardness, thickness, friability and disintegration time for $\mathrm{F} 1$ batch was found to be $[497 \pm 5 \%, 3.3 \pm 0.17,4.00 \pm 0.005,0.81 \%$, 28] respectively, For F2 batch [506 $\pm 5 \%, 3.13 \pm 0.01$, $3.66 \pm 0.023,1.43 \%, 25]$ respectively, For F3 batch $[502.5 \pm 5 \%, 3.13 \pm 0.01,3.96 \pm 0.001,1.8 \%, 32]$ respectively.

Conclusion: The formulated herbal tablets were used to manage arthritic pain. Based on the results, it is concluded that the formulation and evaluation of herbal tablets were good.

Keywords: Nyctanthes arbor-tristis, Anti-pyretic, Analgesic, Anti-inflammatory, Herbal tablets, Arthritis

(C) 2020 The Authors. Published by Innovare Academic Sciences Pvt Ltd. This is an open access article under the CC BY license (http://creativecommons.org/licenses/by/4.0/) DOI: http://dx.doi.org/10.22159/ijcpr.2020v12i3.38299. Journal homepage: https://innovareacademics.in/journals/index.php/ijcpr

\section{INTRODUCTION}

Nyctanthes arbor-tristis is a traditional medicinal plant, which belongs to family Oleaceae. The Nyctanthes arbor-tristis is a shrub or tree having fragrant flowers. The plant generally grows in the tropical and subtropical regions [1-3]. The Nyctanthes arbor-tristis having various names like Parijat, Night Jasmin, Coral Jasmin, Harsinghar, etc. There are several Hindu religious stories related to the Nyctanthes arbor-tristis (Parijat). The holistic connection of the Parijat plant with Bhagwat Purana, The Mahabharata and Vishnu Purana. The Nyctanthes arbor-tristis is called as "Tree of Sorrow" because of the loss of the flowers their brightness during day time. The plant name arbor-tristis means the sad tree $[4,5]$.

The present research is focus on the Arthritis, Nyctanthes arbortristis leaves were proven activity to cure Arthritis and gives relief from fever, pains and inflammation. The whole plant having various medicinal activities like anti-fungal, anti-diabetic, anti-oxidant [6, 7].

Arthritis means joint inflammation and it is chronic autoimmune disease occurs in any age group of peoples. The most common form of arthritis are Osteoarthritis and Rheumatic arthritis. Arthritic conditions tend to involves pain, aching, stiffness and swelling in and around one of more joints. The symptoms can develop gradually or suddenly [8].

According to the Centers for Diseases and Prevention (CDC) Arthritis is more common among adults aged 65 y or older, but it can affect peoples of all ages, including children. The cause of arthritis is the breakdown of cartilage. The function of Cartilage to protect a joint and allowing function smoothly. About $1 \%$ of the population is affected by arthritis women's are three times more affected as compared to men's. The prepared tablets were used to cure Arthritis and gives relief from fever, joint pain and inflammation [9].

\section{MATERIALS AND METHODS}

\section{Materials}

Nyctanthes arbor-tristis leaves were collected from the local area dried, powdered and used as an antipyretic, analgesic, anti-inflammatory to cure arthritis, joint pains etc. The excipients used in the formulation are Methylcellulose is used as disintegrate, Magnesium stearate is used as a lubricant, Lactose is used as the diluent, Talc is used as a lubricant and gives the pleasant appearance to the tablet, and Acacia, HPMC-10,
Sodium alginate these three excipients are used as the binder for the preparation of wet granulation.

\section{Methods}

Preparation of dry powder of nyctanthes arbor-tristis leaves

Collection of fresh leaves of Nyctanthes arbor-tristis from the local area. Clean the leaves by using distilled water. Leaves are dried at room temperature for a few days. The hot air oven is used for the complete drying of leaves. The dried leaves are collected and grind in a mixer to make a fine powder.

\section{Preparation of $1 \%$ acacia solution}

Take $100 \mathrm{ml}$ distilled water in a beaker. Take $1 \mathrm{gm}$ of acacia powder and mix in $100 \mathrm{ml}$ distilled water. Stir continuously until all powder was mix properly.

\section{Preparation of 1\% HPMC-10 solution}

Take $100 \mathrm{ml}$ distilled water in a beaker. Take $1 \mathrm{gm}$ of HPMC-10 powder and mix in $100 \mathrm{ml}$ distilled water. Stir continuously to form a jelly-like appearance.

Preparation of $1 \%$ sodium alginate solution

Take $100 \mathrm{ml}$ alcohol in a beaker. Add $1 \mathrm{gm}$ of Sodium alginate powder in $100 \mathrm{ml}$ alcohol. Stir properly to mix well.

\section{Formulation of herbal tablets}

In this formulation, the dried leaves powder of Nyctanthes arbortristis was used to form a tablet dosage form. The formulation was done by following the wet granulation process and further compression by ing tablet punching machine.

\section{Wet granulation method}

Weigh all ingredients accurately, mix well and triturate by using mortar and pestle. The prepared 1\% binding agent was added slowly to form a damp mass. Damp mass was transfer through sieve no. 22. Prepared granules are dried at room temperature. The well dried granules are ready for compression. 
Table 1: Compression of formulation ingredients of tablet

\begin{tabular}{|c|c|c|c|c|}
\hline \multirow[t]{2}{*}{ S. No. } & \multirow[t]{2}{*}{ Ingredients } & \multicolumn{3}{|c|}{ Quantity } \\
\hline & & F1 & F2 & F3 \\
\hline 1 & Nyctanthes arbor-tristis & $250 \mathrm{mg}$ & $250 \mathrm{mg}$ & $250 \mathrm{mg}$ \\
\hline 2 & Methyl cellulose & $180 \mathrm{mg}$ & $180 \mathrm{mg}$ & $180 \mathrm{mg}$ \\
\hline 3 & Magnesium stearate & $20 \mathrm{mg}$ & $20 \mathrm{mg}$ & $20 \mathrm{mg}$ \\
\hline 4 & Talc & $10 \mathrm{mg}$ & $10 \mathrm{mg}$ & $10 \mathrm{mg}$ \\
\hline 5 & Lactose & $50 \mathrm{mg}$ & $50 \mathrm{mg}$ & $50 \mathrm{mg}$ \\
\hline 6 & Acacia & $1 \%$ & - & - \\
\hline 7 & HPMC-10 & - & $1 \%$ & - \\
\hline 8 & Sodium alginate & - & - & $1 \%$ \\
\hline
\end{tabular}

\section{Evaluation [10]}

\section{Pre-formulation study}

\section{Bulk density}

Bulk density was carried out in $100 \mathrm{ml}$ dried measuring cylinder. Pouring of dried granules in measuring cylinder and calculated by using the following formula;

Bulk density = Mass of the granules/Bulk volume of the granules

\section{Tapped density}

Tapped density was carried out by pouring of dried granules in 100 $\mathrm{ml}$ measuring cylinder.100 tapping was done, note down the volume and calculate by using the following formula;

Tapped density= Granules weight/Volume of tapped granules

\section{Hausner's ratio}

Hausner's ratio is the ratio of the tapped density of granules to the bulk density of granules. Calculated by using the following formula. Table 2 shows the flow property of granules.

Hausner's ratio= Tapped density/Bulk density

\section{Carr's index}

Carr's index or compressibility index is determined by the following formula. Table 2 shows the flow property of granules.

$$
\text { Carr's index }(\%)=\frac{\text { Tapped density }- \text { Bulk density }}{\text { Tapped density }} \times 100
$$

\section{Angle of repose}

Angle of repose was determined by using the funnel method. Following formula was used to calculate the angle of repose. Table-2 shows the flow property of granules.

$\theta=\operatorname{Tan}^{-1}[\mathrm{~h} / \mathrm{r}]$

Where

$\mathrm{h}=$ height of granule cone formed.

$\mathrm{r}=$ radius of the granule cone formed.

Physical evaluation of tablets $[11,12]$

The tablets were subjected to the following evaluation tests.

\section{General appearance}

The general appearance and color of tablets were found by visual determination.

\section{Weight variation test}

The weight variation test was performed by following procedure.

Weigh 20 tablets individually and consider as $\mathrm{X}_{1}, \mathrm{X}_{2}, \mathrm{X}_{3}, \ldots . . \mathrm{X}_{20}$. Determine the average weight of 20 tablets $X=\left(X_{1+} X_{2+} X_{3+\ldots}+X_{20}\right) / 20$. The individual weight was compared with the upper limit and lower limit. Not more than two of the tablets differs from the average weight by more than the \% error listed, and no tablets differ by more than double that percentage. Results are shown in table 5.

Table 2: Scale of flowability

\begin{tabular}{llll}
\hline Flow character & Hausner's ratio & Carr's index (\%) & Angle of repose (०) \\
\hline Excellent & $1.00-1.11$ & $\leq 10$ & $25-30$ \\
Good & $1.12-1,18$ & $11-15$ & $31-35$ \\
Fair & $1.19-1.25$ & $16-20$ & $36-40$ \\
Passable & $1.26-1.34$ & $21-25$ & $41-45$ \\
Poor & $1.35-1.45$ & $26-31$ & $46-55$ \\
Very poor & $1.46-1.59$ & $32-37$ & $56-65$ \\
Very, very poor & $>1.60$ & $>38$ & $>66$ \\
\hline
\end{tabular}

Table 3: Weight variation tolerance

\begin{tabular}{lll}
\hline S. No. & Average weight of tablets(mg) & Max.\% difference is allowed \\
\hline $\mathbf{1}$ & 80 or less & $10 \%$ \\
$\mathbf{2}$ & $80-250$ & $7,5 \%$ \\
$\mathbf{3}$ & More than 250 & $5 \%$ \\
\hline
\end{tabular}

\section{Hardness and thickness test}

For each formulation, the hardness and thickness of 20 tablets were determined. Hardness test was determined by Monsanto hardness tester and the thickness of tablets was determined by Vernier Calipers. Results are shows in table 5.

\section{Friability test}

Friability of a tablets can determine in a laboratory by Roche friabilator. The friabilator consists of plastic chamber that rotates at 25rpm, dropping the tablets through a distance of six inches in the friabilator, which is then operated for 100 revolutions. The tablets are reweighed. Compress tablets loss less than $0.5 \%$ to $1.0 \%$ of the tablet weight are considered acceptable. Results are shown in table 5.

\section{Disintegration time}

This test was a time required for the tablet to separate into particles, the disintegration test measure only of the time required under a given set of aconditions for a group of tablets to disintegrate into particles. This test was performed to identify the disintegration of tablet in a specific time period. 


\section{RESULTS}

The formulation was prepared by wet granulation method were tested for pre-formulation studies for the effective evaluation of tablets. All the evaluated pre-formulation parameters are shown in table 4. Based on the pre-formulation study the flow property of granules was good. The physical parameters of compressed tablets were shown in table 5 . The compressed tablets color was Greenish white for F1 and F3, Dark greenish-white color for F2. The weight variation test, hardness, thickness, friability and disintegration time were shown in table 5.

Table 4: Pre-formulation parameters for herbal tablets

\begin{tabular}{|c|c|c|c|c|}
\hline S. No. & Pre-formulation parameters & F1 & F2 & F3 \\
\hline 1 & Bulk density & $0.267 \mathrm{~g} / \mathrm{cm}^{3}$ & $0.29 \mathrm{~g} / \mathrm{cm}^{3}$ & $0.18 \mathrm{~g} / \mathrm{cm}^{3}$ \\
\hline 2 & Tapped density & $0.325 \mathrm{~g} / \mathrm{cm}^{3}$ & $0.33 \mathrm{~g} / \mathrm{cm}^{3}$ & $0.23 \mathrm{~g} / \mathrm{cm}^{3}$ \\
\hline 3 & Carr's index & $17.84 \%$ & $12.12 \%$ & $21.73 \%$ \\
\hline 4 & Hausner's ratio & 1,21 & 1.14 & 1.27 \\
\hline 5 & Angle of repose & 27.29 & 25.74 & 26.22 \\
\hline
\end{tabular}

Table 5: Physical parameters for herbal tablets

\begin{tabular}{|c|c|c|c|c|}
\hline S. No. & Parameters & F1 & F2 & F3 \\
\hline 1 & Weight variation test & $497 \pm 5 \%$ & $506 \pm 5 \%$ & $502.5 \pm 5 \%$ \\
\hline 2 & Hardness $\left(\mathrm{kg} / \mathrm{cm}^{2}\right)$ & $3.3 \pm 0.17$ & $3.13 \pm 0.01$ & $3.13 \pm 0.01$ \\
\hline 3 & Thickness (mm) & $4.00 \pm 0.005$ & $3.66 \pm 0.023$ & $3.96 \pm 0.001$ \\
\hline 4 & Friability test (\%) & $0.81 \%$ & $1.43 \%$ & $1.8 \%$ \\
\hline 5 & Disintegration test (min) & 28 & 25 & 32 \\
\hline
\end{tabular}

\section{DISCUSSION AND CONCLUSION}

Nyctanthes arbor-tristis was a traditional medicinal plant which having various medicinal activities but present research was focused on Arthritis and antipyretic, analgesic and anti-inflammatory activity. The leaves powder was used to formulate tablets. Wet granulation was done by using different binders and making three batches like F1,F2,F3. Preformulation study was carried out and gives good flow properties of prepared granules. The compression of prepared tablets, were evaluated and gives satisfactory results. The batch F3 was more disintegration time as compared to F1 and F2 batch. Based on the results it is concluded that the formulation and evaluation are good. The pharmacological evaluation is required for the treatment of Arthritis.

\section{ACKNOWLEDGMENT}

The Authors are thankful to Principal Dr. R. Y. Patil and Dr. M. S. Kalshetti, Assistant Professor, D. S. T. S. Mandal's College of Pharmacy Solapur, Maharashtra, India, for his guidance and support.

\section{FUNDING}

Nil

\section{AUTHORS CONTRIBUTIONS}

All the authors have contributed equally.

\section{CONFLICT OF INTERESTS}

Declare none

\section{REFERENCES}

1. Pushpendra Kumar Jain, Arti Pandey. The wonder of Ayurvedic medicine-nyctanthes arbor-tristis. Int J Herbal Med 2016;4:9-17.
2. Champa Rani, Sunaina Chawla, Manisha Mangal, Subhash Kajla, AK Dhawan. Nyctanthes arbor-tristis linn. A sacred ornamental plant with immense medicinal potentials. Indian J Traditional Knowledge 2012;11:427-35.

3. VS Jadhav, VB Ghawate. Evaluation of combined wound healing activity of ethanoic extract of leaves of Murraya koenigii and nyctanthes arbor-tristis. Drug Invention Today 2017;9:24-7.

4. https://en.wikipedia.org/wiki/Nyctanthes_arbor-tristis. [Last accessed on 10 Dec 2019]

5. Ashwani Kumar, Beenu Rathi, Vani Tyagi. Systemic review on anti-sciatica plant "Night Jasmine". Int J Curr Microbiol Appl Sci 2017;6:1018-35.

6. S Bansal, AJ Bharati, YK Bansal. In vitro callogenesis and phytochemical screening of Harsingar a multipotent medicinal tree. Int J Pharmtech Res 2013;5:1786-93.

7. Jadhav Santosh, Patil Manojkumar. A review on: nyctanthes arbor-tristis linn. Rejuvenating herbs. Int J Res Pharm Pharm Sci 2016;1:54-62.

8. https://www.medicalnewstoday.com/articles/7621.php. [Last accessed on 10 Dec 2019]

9. Jyoti B Wadekar, Ramesh L Savant, Unnati B Patel. Rheumatoid arthritis and herbal drugs: a review. J Pharmacol 2015;4:311-8.

10. Micheal E Aulton. Aulton's pharmaceutics: the design and manufacture of medicines. 3rd editions China; Elsevier publishers; 2007. p. 178, 355-356.

11. Haritha B. A review on evaluation of tablets. J Formulation Sci Bioavailability 2017;1:107.

12. Hitesh Chaturvedi, Ayush Garg, Udiabhan Singh Rathore. Postcompression evaluation parameters for tablets-an overview. Eur J Pharm Res 2017;4:526-30. 